\title{
O livro de Jonas: um Deus que abraça todas as pessoas
}

\section{The book of Jonah: a God who embraces all people}

\author{
El libro de Jonás: un Dios que abraza a todas las \\ personas
}

\author{
Altierez Sebastião dos Santos*
}

\begin{abstract}
RESUMO
O Brasil tem visto crescer a violência religiosa, intolerância e fundamentalismo como uma espécie de cultura religiosa. Esse fenômeno tem produzido incontáveis vítimas. Mas a própria Bíblia condena tal mentalidade. O Livro de Jonas apresenta uma mensagem de diálogo e respeito com as diferentes culturas e religiões. No presente artigo destacamos a narrativa e a personagem bíblica de Jonas como defensoras da diversidade e contrárias à intolerância e fundamentalismo.

Palavras-chave: Livro de Jonas; Jonas; violência religiosa; intolerância; cultura de paz.
\end{abstract}

\begin{abstract}
Brazil has seen religious violence, intolerance and fundamentalism as a kind of religious culture. This phenomenon has produced countless victims. But the Bible itself condemns such a mentality. The Book of Jonah presents a message of dialogue and respect for different cultures and religions. In this article we highlight the narrative and biblical character of Jonah as defenders of diversity and against intolerance and fundamentalism.

Keywords: Book of Jonah; Jonah; religious violence; intolerance; culture of peace.

RESUMEN

Brasil ha visto crecer la violencia religiosa, intolerancia y fundamentalismo como una especie de cultura religiosa. Este fenómeno ha producido innumerables víctimas. Pero la misma Biblia condena tal mentalidad. El Libro de Jonas presenta un mensaje de diálogo y respeto con las diferentes culturas y religiones. En el presente artículo destacamos la narrativa y el personaje bíblico de Jonás como defensoras de la diversidad y contrarias a la intolerancia y fundamentalismo.

Palabras clave: Libro de Jonas; Jonas; violencia religiosa; intolerancia; cultura de paz.
\end{abstract}

\section{Introdução: contexto atual}

O livro de Jonas é portador de uma fina teologia que pretende expor a rudeza das nossas relações do Deus, seja como sujeitos da sociedade, seja como coletividade. Sua mensagem mais central é que a relação com o sagrado não conhece fronteiras e não se dá segundo as articulações humanas, tão lamentavelmente representadas em nosso tempo pela promiscuidade entre

* Doutorando em Ciências da Religião pela Universidade Metodista de São Paulo. Pesquisador do Grupo de Pesquisa RIMAGO. Bolsista CAPES. E-mail: altierezss@gmail.com 
os poderes religiosos e os poderes do deus mercado. O "sinal de Jonas", em sua singeleza e simpatia, é dirigido hoje contra tantas situações cometidas em nome do bom "Deus do Céu e da terra". O acirramento nas posições religiosas (frequentemente manipuladas por pautas políticas), nas questões de gênero, raça, etnia, fronteiras inaugura conflitos em nome de questões de pureza e santidade (convertidas no binarismo bem versus mal). "A violência grita ao destituir palestinos de seus lares e famílias, ao submeter mexicanos a uma pseudossuperioridade norte-americana e ao subjugar paulistanos às bordas esquecidas do bem-estar social" (CARDOSO, 2014, p.66).

Em um País cuja violência foi um componente histórico de sua formação e continua sendo mediação e finalidade em dinâmicas sociais, o elemento da intolerância religiosa tem reforçado antigos processos de violência e criado novos (SANTOS, 2017). Exemplos dessa realidade são muitos e vão desde linchamentos a pessoas identificadas fora da perspectiva "cristã" até agressão de religiosos e templos incendiados.

Legado da aliança do catolicismo com o poder estatal, a não pertença à fé cristã foi assumida por ondas pentecostais e neopentecostais em intensidades variadas. Esse fenômeno de manutenção do discurso de ódio associou-se aos ritos de exclusão racial e econômica, a violência religiosa ganha contornos dramáticos, cumulando em casos de linchamentos e múltiplas formas de violência. Uma população analfabeta, mas informada por posicionamentos de purismo religioso e convicta da possibilidade de ministrar justiça popular aos desajustados tem produzido lamentáveis episódios de intolerância (MARTINS, 2015). Eventos dessa natureza, que podem ser mapeados pelo registro da mídia ou da justiça são, no entanto, uma pequena parte de um drama que é capilar na sociedade (SANTOS, 2018). Por estar entranhada na cultura brasileira, a violência racial, de gênero, de classe e, por fim, de religião, é difícil de medir e produz todos os dias incontáveis vítimas. Dados do Disque Denúncia notificavam que no fim de 2017 havia um registro de natureza violenta a cada quinze horas ${ }^{1}$, número que certamente é maior. $\mathrm{O}$ maior número de vítimas provém dos cultos afro-brasileiros e dos católicos; do outro lado, adeptos de grupos fundamentalistas cristãos.

Nestas notas procuramos analisar a narrativa de Jonas por meio dos elementos narrativos e resgatando igualmente o contexto no qual surgiu a obra, pois afinal, "nada há de novo debaixo do sol", como ensina o Eclesiastes $(1,9)$.

\footnotetext{
Fonte: <https://brasil.estadao.com.br/noticias/geral,brasil-registra-uma-denuncia-de-intolerancia-religiosa-a-cada-15-horas, 70002081286>. Acesso em 30 mai 2018.
} 


\section{Contexto histórico do Livro de Jonas}

O Livro de Jonas reage a uma teologia racial que surgiu no pós-Exílio da Babilônia quando os judeus estendem para os exilados os preceitos de santidade e de afastamento em relação aos opressores. Também será nesse tempo que se darão os primeiros passos de afirmação do monoteísmo e recusa dos outros deuses como elementos estrangeiros.

O personagem Jonas filho de Amati é relacionado na Bíblia na primeira vez em 2Rs 14,25, passagem que o situa no reinado do rei Jeroboão II, que governou o Reino do Norte no século VIII a.C., ou seja, muito tempo antes da provável redação da novela que leva seu nome. Contudo sabemos que essa narrativa é uma reação a um contexto histórico específico, ao qual suas imagens e alegorias precisam ser conectadas para que façam sentido. É possível que a menção ao profeta tenha sido um recurso para dar autoridade e aceitação ao escrito repleto de fantasia e bom humor que era, afinal, uma denúncia contra a profecia oficial que queria isolar o povo da Aliança de todos os outros povos ( $\mathrm{Ne} 9,2)$.

Sua redação final não é um consenso entre os especialistas. Apesar da dificuldade em se aprofundar na origem dos aspectos literários do livro de Jonas, é possível saber que, pela forma narrativa - que guarda semelhanças com as lendas de Elias e Eliseu - o texto pode remontar às antigas tradições orais (CARDOSO, 2014, p. 59). José Luis Sicre Díaz o situa no V século a.C., pelo vocabulário tardio, porém alertando que poderia ser até do III século a.C. Nelson Kilpp supõe que seja do IV século a.C. por traços de costumes persas e pela expressão "Deus do Céu” (Jn 1,9). Vincent Mora coloca a dificuldade de datar o texto, que parece ter tido poucas glosas e acréscimos e Mercedes Lopes também o situa no $\mathrm{V}$ século a.C. por conta da teologia deuteronomista e pela reação à política de Neemias. Há semelhanças entre as redações de Jonas, Jeremias e Joel. Jeremias foi atualizado antes, durante e depois do Exílio. De todo modo, a partir das contribuições da linguística e da arqueologia é provável que o relato de Jonas seja do fim do período persa (KILPP, 1994). Encontrado em um contexto tardio em Judá, o texto não possui palavras gregas, podendo ser situado antes de 250 a.C.

Em todo caso, sua redação parece ter sido dada no pós exílio no contexto da formulação de teorias que explicassem o sofrimento de todo o povo e na tentativa de propor uma nova teologia para a religião e a nação. Uma dessas teorias é a representada pelos livros de Esdras (Es 8) e Neemias ( Ne 11-12), que propunham um fechamento do povo aos estrangeiros, causadores de sua desgraça. Não apenas fechamento, mas também exclusão, aversão. Fortalecia-se o ideal de pureza religiosa e se estabelecia um ideal teocrático 
com centralidade do Templo e da Lei. Essa ideologia foi vitoriosa, mas houve projetos alternativos.

\section{Um projeto de exclusão}

Esse mesmo projeto foi o que marginalizou os habitantes da terra, que não conseguiam comprovar por meio de extensas genealogias o pertencimento ao "povo de Israel", ficando excluídos da vida religiosa e social. O texto de Ez 22,23-31 faz uma violenta separação entre os puros de Javé e o "povo da terra": "Busquei entre eles um homem capaz de construir um muro e capaz de pôr-se na brecha, em prol da nação, para que não a destruísse, mas não o encontrei" (Ez 22,30). Os grupos excluídos encontraram apoio e resistência em outros textos, como Is 56,3-7: "Eu lhes darei, na minha casa e dentro dos meus muros, monumento e nome mais preciosos do que teriam com filhos e filhas" (Is 56,5). Os livros de Abdias e Jonas situam-se no contexto deste debate, oferecendo duas propostas distintas; a de Abdias - que recusa os não israelitas (como Edom e outros) - e a de Jonas - que anuncia até mesmo aos piores estrangeiros (Nínive, a sede do império assírio) (cf. SCHWANTES, 2006, p. 17).

Os livros de Rute e de Jonas firmam-se nessa perspectiva, o primeiro ao trazer uma moabita para ser a ancestral do rei Davi e o segundo ao anunciar a complacência de Javé para com os estrangeiros. Ambos, contudo, firmam-se em antiga tradição bíblica: "Por ti serão benditos todos os clãs da terra" (Gn 12,3). Há ecos dessa centralização excludente em relatos como o de Ester, nos quais se identifica o fechamento cultural aos estrangeiros e "diferentes" a que se inclinou o povo de Israel (KILPP, 1994, p. 24). O livro de Jonas tem a intenção de contrapor-se à exclusão religiosa das classes dominantes do pós-exílio. "Sua característica didática aqui, que mescla sentimentos da tragédia e comédia, projeta-se como um clamor visceral de empobrecidos - estrangeiros, viúvas, o 'povo da terra' - prestes a serem desterrados. A relação de fronteira e violência são primordiais" (CARDOSO, 2014, p. 60).

Pistas para a compreensão do contexto histórico podem ser deduzidas pela forma como o redator apresenta o relacionamento do personagem Jonas com os ninivitas e por extensão à Assíria. Este império é lembrado em alguns profetas como a imagem da maldade, graças às práticas militares e violência praticada contra povos vencidos. Por ser um ponto de passagem entre o Oriente e o Ocidente, a Assíria sofreu historicamente com o deslocamento de tropas estrangeiras por seu território e as consequências que isso trazia. Devido a isso, ela desenvolveu uma prática militar avançada e à altura das violações pelas quais passara até o século VIII a.C., quando se destaca no cenário regional como uma potência. 
Foi nessa época que o rei Senaqueribe escolheu Nínive para sua residência (2Rs 19,36; Is 37,37$)$. Como era capital de um império que devastou totalmente o reino do Norte, em 722 a.C., e que havia dominado a Judeia, obrigando-a a pagar tributos durante o período do rei Manassés (698-643 a.C.), a cidade de Nínive era para o povo bíblico um símbolo de violência e maldade. Naum ( $\mathrm{Na}$ 1,3) e Sofonias (Sf 2,13-15) profetizaram contra Nínive, anunciando sua destruição (LOPES, 2010, p. 24).

Essa tensão pode servir de indício para situar historicamente o livro no V século a.C., após o exílio da Babilônia, quando a tentativa de reconstruir Israel como uma comunidade nacional passava por projetos como o que conhecemos de Esdras e Neemias. Nesses dois livros há proibições para o casamento entre israelitas e pessoas dos povos vizinhos (Ne 10,31; 13,23-25; Esd 9,2), além de ordens de separação de casais constituídos dessa forma. Esdras relata/cria uma difícil situação ao ordenar que maridos mandassem embora suas esposas não israelitas $(9,1-10 ; 10,44)$. Quando a Assíria caiu em 612 a.C. com a ascensão do império persa, a mudança de dominação foi saudada como um avanço para a comunidade judaica, que, por intermédio de sua classe sacerdotal conseguiu favores dos novos senhores.

Neemias e Esdras eram apoiados pelo império e chegaram até a aceitar que a lei de Deus fosse colocada e pé de igualdade com a lei do rei da Pérsia. Esdras dizia: "Quem não obedecer a lei dos eu Deus, que é a lei do rei, será castigado rigorosamente, com a morte ou exílio, multa ou prisão" (Esd 7,26) (LOPES, 2010, p. 8).

O livro do Profeta Naum narra a destruição de Nínive e faz essa narrativa com alegria, comemorando a queda de um império que tanto mal trouxe ao mundo. Jeremias 36 entende que Nínive não tem conversão. De modo algum. A oposição bíblica à Assíria e tudo o que ela representou era, no entanto, continuava firme na memória do povo, embora no século IV, tido por alguns como tempo da redação do livro de Jonas, o império assírio já havia desaparecido há tempos e o próprio império persa também estava estivesse em colapso.

\section{Gênero do livro de Jonas e sua estrutura}

A narrativa de Jonas foi situada, na Bíblia, entre os doze profetas menores, um conjunto peculiar, distinguido por dois grupos. O primeiro livro, de Oséias tem traços deuteronomistas, o segundo livro, de Joel, tem linguagem apocalíptica. A estes dois livros seguem se os livros de Amós, Abdias, Jonas e Miqueias, que se relacionam à escola deuteronomista, como Oséias, do qual estão próximos pela tônica e conteúdos. Dentro desse conjunto, Abdias e Jonas possuem uma correspondência temática, ou antes, uma tensão, pois o 
primeiro celebra a destruição dos estrangeiros edomitas (considerado povo irmão), enquanto o segundo coloca ao alcance da graça de Javé os estrangeiros. Mas não quaisquer estrangeiros: os assírios, associados pelos israelitas à crueldade e violência (SCHWANTES, 2006, p. 17).

Embora colocado entre os profetas, o livro de Jonas trata-se de uma novela com inclinações sapienciais e que mistura elementos como fábula e realidade (MORA, 1983, p. 37). O livro é uma reação à ideologia contida, por exemplo, nos livros de Esdras e Neemias, que era excludente para com os povos que não haviam sofrido o exílio. Essa exclusão era baseada na lei, na pureza racial e no Templo. O profeta Jonas entra em cena representando exatamente essa atitude de fechamento e de exclusão. A narrativa quer tornar risível essa pretensão. Daí o recurso às imagens fantásticas, ao humor e a uma atitude de Deus que ainda hoje questiona exclusivismos religiosos. A propósito, o nome do personagem Jonas, em hebraico, significa "pomba" e "Amati" pode ser traduzido como "veracidade", resultando, logo de início em uma imagem que traz um questionamento: "o que a pomba, filha da veracidade, quer comunicar?” (LOPES, 2010, p. 8).

Sobre a caracterização literária do livro de Jonas, comparando-o aos gêneros narrativos da Bíblia, é possível recusar as categorias de saga e conto por não se constituir de uma narrativa longa e seriada ou por uma cena única restrita a poucos personagens. Por razões elementares também não pode ser caracterizado como fábula, mito ou história² (MORA, 1983, p. 37).

O gênero novela parece compreender melhor o livro como todo, visto conter "uma sequência limitada de eventos que é trazida à conclusão na luz de um incidente inicial". Ao contrário do conto, a novela não carrega simples relação de causa e efeito, mas um enredo que une toda a trama, construído a partir de pequenos e subordinados subenredos.[...] É importante salientar que textos não possuem gêneros puros, mas carregam influências de outras formas literárias. Assim é com Jonas, que possui elementos de outros gêneros (CARDOSO, 2014, p. 57).

\section{Elementos literários}

Dentre os elementos literários, nota-se traços cômicos: um profeta que escolhe uma viagem marítima para fugir do Deus Criador das águas; o

\footnotetext{
2 Carreira (2005) realizou uma análise comparativa do texto de Jonas com outros textos semelhantes da antiguidade mediterrânea. Em sua pesquisa, resgatou um antigo conto marítimo egípcio que possui motivos semelhantes ao de Jonas e apresentou um conto egípcio que possui motivos semelhantes à Odisséia, às aventuras de Simbad e outras estórias que tiveram como fundo a cultura mediterrânea. Para o autor, se esses dois exemplos mostraram que pode acontecer uma circulação cultural entre egípcios e gregos, pode ocorrer o mesmo entre outros povos. Por isso ele acredita que Jonas seja fruto dessa circulação, visto que seus motivos também são encontrados em outros contos.
} 
barco que cobra pelo transporte e o peixe que o leva sem cobrar. O profeta vomitado e a penitência dos animais também se insere nessa perspectiva. Também há elementos trágicos na narrativa, sendo um indício de que ela não serve apenas para divertir: um herói que falha de forma trágica, a desventura que lhe sucede, a catástrofe de que ele é portador, o próprio desejo de morte $(4,3,8)$,

O texto provoca, questiona e intriga pelo recurso ao fantástico e ao exagero. A figura do peixe, com seu tamanho descomunal, que abriga o profeta e o leva mais próximo de seu destino (Jn 2,1.11), o tamanho da cidade de Nínive que levava três dias para ser atravessada (Jn 3,3), o mau humor, teimosia e indiferença do profeto, que o tornam caricato ao não querer pregar para os ninivitas (Jn 4,2), a desproporção entre a compaixão de Jonas pela "sua" mamoneira e o desprezo pelo povo de Nínive. Todas essas são imagens com correspondência no mundo bíblico e especificamente no contexto histórico já mencionado.

O elemento da ironia é presente no texto, já no início, quando os marinheiros rezam e Jonas, um judeu piedoso, vai dormir. Os marinheiros, mesmo sabendo que ele é o problema, se preocupam com ele e não querem jogá-lo na água, isso mostra a misericórdia que ele não tem. Os marinheiros de Társis provavelmente adoravam Poseidon, mas Jonas diz que é temente a Javé, que fez o céu e a terra. Eles então oferecem sacrifícios a esta divindade, não a Poseidon, enquanto Jonas não se preocupa com isso, fazendo uma inversão de papéis, o que indica uma crítica. Possivelmente o salmo do capítulo 2 foi inserido no conjunto da história para reforçar a ironia contra Jonas, que foi colocado no ventre do peixe, imagem que pode indicar que Deus fez com que ele descesse para dentro de si para pensar (KILPP, 1994). Mas mesmo lá, Jonas continuou sendo um judeu nacionalista, entoando uma oração oficial. Mas Jonas é teimoso e nem o peixe o suporta, vomitando-o.

Outra ironia é dada no fato de que com a pregação de Jonas todo o povo se converte, inclusive os animais. Nenhuma cidade estrangeira se converteu totalmente, mas aqui a mensagem é para os judeus nacionalistas que não acreditavam na possibilidade de conversão dos estrangeiros, conforme está em 3,10. Converter-se significa seguir o caminho da vida, da sensibilidade, do amor. Eles se convertem de sua vida anterior.

\section{Divisões da narrativa}

O texto de Jonas pode ser dividido em duas partes correlacionadas, de acordo com a classificação de Vincent Mora (1983). Outra forma de dividir o texto é por meio de "quatro cenas", conforme a classificação de Milton 
Schwantes (2006). De qualquer forma, uma não invalida a outra, pois os quadros do livro de Jonas mostram eventos distintos como a tempestade no mar e a liturgia penitencial dos ninivitas. Também é possível dividir o texto em duas cenas, uma no mar (Jn 1 e 2) e uma na terra (Jn 3 e 4).

Quadro 1: As duas partes da novela de Jonas. MORA, 1983, p

\begin{tabular}{|c|c|c|}
\hline Primeira parte & Segunda Parte \\
\hline $1,1-1,3$ & Deus envia Jonas em missão aos gentios & $3,1-3,4$ \\
\hline $1,4-1,16$ & Deus e os gentios & $3,5-3,10$ \\
\hline $2,1-2,11$ & Deus e Jonas & $4,1-4,11$ \\
\hline
\end{tabular}

Na primeira cena (1,1-17) Jonas recebe o oráculo de Javé com a missão de que se dirija a Nínive, com o objetivo de demovê-los de sua maldade, o profeta faz exatamente o contrário ao tomar a direção oposta, embarcando para Társis, cidade cuja simbologia atribuída por Isaías 66,19 é o local onde "Javé não é conhecido", situada na extremidade do mundo, próxima ao caos e, paradoxalmente, por essas características, representando para o profeta Jonas "um lugar agradável e seguro na borda da não-existência" (ACKERMAN, 1997, p. 252).

Além de ser citada em Isaías 66,19, ela é mencionada em Ezequiel 27,12, em Jeremias 10,9 e em Isaías 60,19. É uma terra distante, de comércio. O texto traz detalhes do navio e da navegação e, fato interessante, apresenta Jonas como adorador de Javé, o deus que fez "os céus e a terra" $(1,9)$, portanto onipresente, mas do qual ele acredita poder ignorar e inclusive fugir. Mas Javé quer impedir a fuga e manda uma tempestade que coloca o barco em perigo. A tripulação teme a fúria das ondas e tira a sorte para saber se há alguém no barco que poderia ser o responsável pela intempérie. A sorte recai sobre Jonas e ele é encontrado no fundo do navio dormindo! Ele assume a culpa e pede que o lancem ao mar, mas os marinheiros, de religião diferente, não querem fazer isso. Ele insiste, eles então o jogam, com tristeza, rezam para Javé e acreditam em seu poder (Jn 14,16). O mar se acalma e Jonas afunda.

A segunda cena acontece em 2,1-11 sendo que os primeiros dois versículos são uma continuação da narrativa do capítulo 1, quando Javé envia um "grande peixe" que o embarca e navega com Jonas por três dias pelo fundo do mar. A partir do versículo 3 ocorre a inserção do salmo penitencial que nitidamente não se assemelha ao restante do livro. Instalado no interior do peixe, mas angustiado, Jonas reza a Javé de forma humilde e suplicante e então Javé ordena ao peixe-veículo que ele devolva Jonas em terra firme.

A terceira cena, que se inicia em 3,1 , se conecta com a narrativa interrompida em 1,17 e 3,1 se relaciona com 1,1. Diferente da primeira cena - quando 
Jonas desobedece a Javé e não vai a Nínive -, em 3,1 ele acata o divino mandato. À cidade, que era tão distante quanto grande, ele chega em apenas um dia de viagem e, apesar de serem necessários três dias para percorrê-la, Jonas aparentemente atinge toda a "grande cidade" com apenas algumas poucas palavras: "ainda quarenta dias e Nínive será destruída" $(3,4)$. A repercussão, no entanto, se dá na ordem inversa da mensagem lacônica: o rei as pessoas e até os animais acolhem a mensagem do profeta e procuram mudar de vida.

A quarta cena traz nova surpresa: após a nada animada pregação de Jonas e do resultado desproporcional, ao ver a população acolher sua revelação, ele se zanga seriamente com a divindade quando ela se converte ao povo. Sente-se irado e traído. Não vai embora, contudo, mas se assenta sobre uma cabana para contemplar a cidade, pois ainda acredita que ela será destruída pela cólera divina. À sombra da cabana, que não lhe era suficiente para protegê-lo do sol, Javé faz crescer numa noite uma mamoneira que lhe faça sombra. Na outra noite, Javé manda um verme para comer a mamoneira e ela morre. Jonas, que toma isso como mais uma afronta, continua impassível no seu rancor.

Essa conversão, relacionada à anterior conversão de outros gentios - os marinheiros - coloca em evidência a postura de Jonas: ele fica inconformado com a misericórdia do próprio Deus. Reclama e se lamenta preferindo a morte:

${ }^{1}$ Mas isso trouxe a Jonas um grande desgosto, e ele ficou irado. ${ }^{2}$ Orou então a Javé dizendo: 'Ah! Javé, não era justamente isso que eu dizia quando estava ainda em minha terra? Por isso fugi antes para Társis; pois eu sabia que tu és um Deus de piedade e ternura, lento para a ira e rico em amor e que se arrepende do mal. ${ }^{3}$ Mas agora, Javé, toma, eu te peço, a minha vida, pois é melhor para mim a morte do que a vida.' ${ }^{4} J a v e ́$ disse: 'Está certo que te aborreças?? ${ }^{5} \mathrm{E}$ Jonas tinha saído da cidade e se havia instalado a leste da cidade. Lá construiu uma choça e assentou-se à sua sombra para ver o que aconteceria na cidade. ${ }^{6}$ Então Javé Deus ordenou a uma mamoneira que crescesse sobre Jonas, para dar sombra à sua cabeça e libertá-lo do seu mal. Jonas alegrou-se grandemente por causa da mamoneira. ${ }^{7}$ No outro dia, ao surgir a aurora, Deus mandou um verme que picou a mamoneira, a qual secou. ${ }^{8}$ Quando o sol se levantou, Deus mandou um vento oriental ardente; o sol bateu na cabeça de Jonas e ele desfalecia. Então pediu a morte e disse: 'É melhor para mim morrer do que viver.' 'Deus disse a Jonas: 'Está certo que te aborreças por causa da mamoneira?' Ele respondeu: 'Está certo que eu me aborreça até a morte. ${ }^{10} \mathrm{E}$ Javé disse: 'Tu tens pena da mamoneira, que não te custou trabalho e que não fizeste crescer, que em uma noite existiu e em uma noite pereceu. ${ }^{11} \mathrm{E}$ eu não teria pena de Nínive, a cidade grande, onde há mais de cento e vinte mil pessoas que não sabem distinguir entre direita e esquerda, assim como muitos animais?' (Jonas 4,1-11).

Diferente de outros profetas como Amós, Miquéias ou Jeremias, cujo sofrimento é resultado da não aceitação de suas profecias, aqui temos exata- 
mente o oposto: um Jonas raivoso por que, com sua pregação eficaz, Nínive foi poupada. Sua ira dirige-se enfaticamente contra Deus que se arrependeu do mal que faria aos gentios (Jn 3,10). 'Este 'o mal' que Deus não realiza é, para Jonas, 'um mal grande'! Quem escreveu esta narrativa sobre Jonas sabia escrever!" (SCHWANTES, 2006, p. 19). Na cabana que lhe protege a cabeça do sol fica simbolizada sua decepção e indiferença pelo sucesso alheio. Ali lamenta-se e manifesta sua incompreensão para com a misericórdia de Deus aos outros que ele queria ver destruídos.

\section{Paralelismos da narrativa}

Quadro 2: Ira e misericórdia em Jonas ALMEIDA, 2002, p. 80.

\begin{tabular}{|c|c|c|c|c|}
\hline A & \multicolumn{4}{|c|}{ Irritação de Jonas: 4,1 } \\
\hline & B & \multicolumn{3}{|r|}{ Jonas reconhece a misericórdia divina: 4,2} \\
\hline & & $\mathrm{C}$ & & $\begin{array}{l}\text { Duplo refrão: É melhor para mim morrer do que viver }(4,3) \\
\text { Acaso tens razão para te irritar? }(4,4)\end{array}$ \\
\hline & & & $\mathrm{D}$ & A misericórdia de Deus para com Jonas: 4,5-8. \\
\hline & & $\mathrm{C}$ & & $\begin{array}{l}\text { Duplo refrão: É melhor para mim morrer do que viver }(4,8) \\
\text { Acaso tens razão para te irritar? }\end{array}$ \\
\hline & $\mathrm{B}$ & \multicolumn{3}{|r|}{ Deus conhece a irritação e a falta de misericórdia de Jonas: 4,10 . } \\
\hline $\mathrm{A}$ & \multicolumn{4}{|c|}{ A misericórdia Divina: 4,11. } \\
\hline
\end{tabular}

Quadro 3: Misericórdia em Jonas ALMEIDA, 2002, p. 80.

\begin{tabular}{|c|c|c|c|c|}
\hline A & \multicolumn{4}{|c|}{ Jonas fica irado e ora ao Senhor - v.1,2. } \\
\hline \multirow{3}{*}{} & B & \multicolumn{3}{|c|}{ O pedido de Jonas e a pergunta de Deus - v.3,4. } \\
\cline { 2 - 5 } & & C & \multicolumn{3}{|c|}{ Jonas sai da cidade e descansa - v.5. } \\
\cline { 2 - 5 } & & D & A misericórdia de Deus para com Jonas - v.6. \\
\cline { 2 - 5 } & B & \multicolumn{3}{|c|}{ O sol sai no horizonte, acaba o descanso - v.7,8 } \\
\hline A & \multicolumn{3}{|c|}{ O Senta de Deus e o pedido de Jonas - v.8,9. } \\
\hline
\end{tabular}

Quadro 4: Correspondências em Jonas. ALMEIDA, 2002, p. 79.

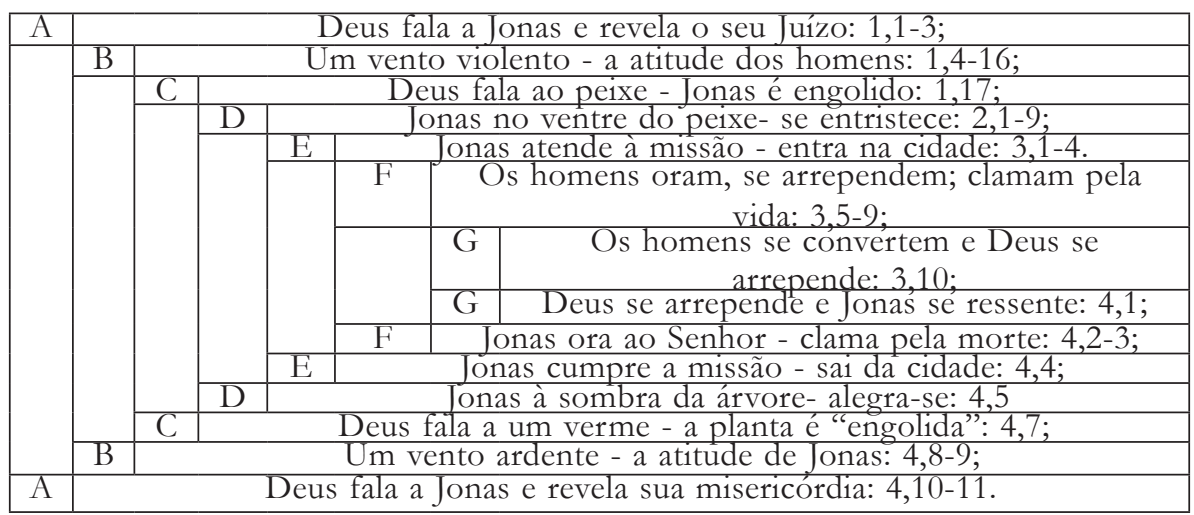




\section{Conexões do livro e do personagem Jonas com a Bíblia}

A primeira impressão que a obra causa é que, quando recebe o mandato divino, Jonas, sem a menor cerimônia se prepara para não cumpri-lo. $\mathrm{O}$ mandato, a propósito, se assemelha ao do profeta Elias em 1 Rs 17,9, onde Deus lhe diz: "Levanta-te e vai a Sarepta" (Síria). Essa relação com Elias é uma fina ironia na qual o autor de Jonas quer trazer para a reflexão a figura e a postura dos profetas (MORA, 1983, p. 13). Da mesma forma outros versículos da narrativa serão retirados de outros escritos, como a liturgia penitencial de Nínive, que se relaciona com (Jr 36,9 e J1 2,15: “Ordenai um jejum! Proclamai uma reunião sagrada!’).

Podemos nos perguntar se não devemos ver no livro de Jonas uma referência arcaica ao profeta Elias. Lembramo-nos, com efeito, que Elias, repleto de zelo de Deus, sacrificou sobre o monte Carmelo centenas de sacerdotes de Baal (1Rs 18,20-40). Não teríamos nesta paródia de Elias que é Jonas uma crítica ao velho profeta? Não podemos fazer melhor que massacrar os sacerdotes e os pagãos? O Deus de Israel não quer a morte dos pagãos, mas que se convertam e vivam (MORA, 1983, p. 33).

Outra expressão que relaciona Jonas a Elias é "longe da face de Javé", que ocorre em Jn 1,3.10. Essa expressão seria o oposto de "manter-se diante da face de Javé", atitude de reverência e obediência típica dos profetas, especialmente Elias (1Rs 18,15; 22,21; Jr 15,19; 18,20). Mais precisamente a expressão "longe da face de Javé" aparece duas outras vezes na Bíblia, em Gênesis, e está ligada ao episódio do fratricídio praticado por Caim (Gn 4,13.16). O mesmo Caim que se irrita e discute com Deus e o mesmo Caim que foge para longe de sua terra, mas que continua protegido de Deus (Gn 4,15). A ligação com Caim aparece ainda no quarto capítulo do livro de Jonas, quando ele sai da cidade e se instala a leste (Jn 4,4) Caim, ao se retirar da presença de Javé, foi para a terra de Nod, “a leste do Éden” (Gn 4,16). Como o profeta Jonas, Caim também se irritou com Deus, por não ter aceito seu sacrifício, mas o do irmão, ao que Deus pergunta a ele "Tens, por acaso, motivo para te irar?" (Gn 4,6-7), basicamente a mesma pergunta de Jn 4,4-9 (MORA, 1983, p. 13;33).

Jonas aparece sob os traços de um Caim ciumento e assassino, sob os traços de um povo submisso e idólatra, sob os traços do povo rebelde aos apelos dos profetas, sob os traços, finalmente, de um Elias que massacra os profetas e sacerdotes de Baal. Jonas, enfim, é um cego: não vê que sua condição em nada difere da dos pagãos, pelo menos quanto ao essencial: Jonas, símbolo de Israel, está em pecado; e, como os pagãos, só deve sua salvação à misericórdia de Deus; talvez seja pior do que os pagãos, porque este Jonas que recusa levar a salvação aos pagãos arde de inveja como Caim e está, como esse, pronto para matar seu irmão (MORA, 1983, p. 44-45). 
As semelhanças entre as narrativas de Jonas, Jeremias e Joel, bem como os versículos reproduzidos em seu texto conectam-no ao texto e cultura bíblica do Antigo Testamento. A influência de Jonas é mencionada no Novo Testamento em diferentes partes, nomeadamente quando é pedido a Jesus um sinal e, segundo Mateus (12, 39-42 e 16, 1-4) e Lucas (11,29-32). A teologia segundo a qual Deus ainda poderia preferir os gentios e estrangeiros parece ser reflexo da teologia proposta por Jonas (Mt 8, 11-12; Mt 20,16; Lc 13, 30; Lc 13, 28-29) (cf. MORA, 1983, p. 71) não apenas para expressar a universalidade da salvação de Deus, mas também a recusa a padrões fechados e exclusivistas.

\section{Conclusão}

O município do Rio lidera no ranking de crimes de intolerância religiosa. O município concentra 55\%dos casos, seguido por Nova Iguaçu (12,5\%) e Duque de Caxias (5,3\%). O tipo de violência mais praticado é a discriminação com $32 \%$, depredação de lugares ou imagens vem em seguida com $20 \%$ e difamação com $10,8 \%$. As religiões como Candomblé, Umbanda e outras religiões de matrizes africanas lideram o índice de denúncias. Candomblé representa 30\%, seguido de Umbanda com 22\% e as demais aparecem com 15\% (O Globo, 30 mai. 20183).

O teor do livro de Jonas é claro. Tem algo a dizer à nossa sociedade hoje e aos que, em nome de quaisquer divindades, promovem a exclusão e o fechamento de horizontes. Mais que uma tentativa de confinamento do sagrado, discursos radicais e puristas geram, agora como antes, vítimas silenciosas em toda parte. Nínive é aqui e além. Uma de suas mensagens é que Deus não se deixa prender aos nossos esquemas. O personagem Jonas ensina que a verdadeira religião é ir ao encontro do outro. Sua história ensina que não é possível fugir do diálogo, que o Espírito não se prende aos nossos esquemas, que Deus está presente em todas as culturas e crenças, que a verdadeira religião consiste na prática da justiça e solidariedade. Conversão é seguir um caminho ético, abandonando o caminho da injustiça e da violência social. Os ninivitas não se convertem a Javé, apenas se arrependem. A mensagem aqui é que não é o deus que se adora que importa, mas o caminho que as pessoas tomam é o que conta.

\footnotetext{
3 “Cresce 56\% o número de casos de intolerância religiosa no Rio". Disponível em: <https://oglobo. globo.com/rio/cresce-56-numero-de-casos-de-intolerancia-religiosa-no-rio-22664376\#ixzz5He5ydNP5>. Acesso em 10 mai. 2018.
} 
A ligação de Jonas e Caim pelo ódio e ciúme que os cega, afasta da face de Deus e os coloca para esperar a morte é uma crítica à religiosidade que procura ter o monopólio da relação com o sagrado. Sua ligação com os profetas coloca também essa perspectiva em relevo. Isso dá ao personagem Jonas e à sua historieta fantástica uma profundidade e atualidade insuspeitas. Coloca a nu as maquinações e falsificações para instrumentalizar a religião. "Quem não quer a salvação de seu irmão, deseja sua morte (...). O Deus de Israel é um Deus de bondade e de ternura” (MORA, 1983, p. 45). Para todas as pessoas, para toda a Criação. Por isso a pergunta final de Deus a Jonas não tem uma resposta. Talvez para que seja respondida por nós.

\section{Referências bibliográficas}

ACKERMAN, James. S. Jonas. In: ALTER, Robert; KERMODE, Frank. Guia literário da Bíblia. Trad. Raul Fiker. São Paulo: Fundação Editora da UNESP, 1997, p. 251-262.

ALMEIDA, Francisco Wellington de O. Teologia do Livro de Jonas. Práxis - Revista Teológica, vol. 6, p. 57-89, 2002.

BÍBLIA DE JERUSALÉM. 6. reimpressão. São Paulo: Paulus, 2002.

CARDOSO, Silas Klein. Por um mundo sem fronteiras: uma leitura em Jonas. Protestantismo em Revista, São Leopoldo, vol. 34, p. 54-68, maio/ago., 2014.

CARREIRA, José Nunes. Motivos egípcios no Livro de Jonas. Didaskalia, Lisboa, vol. 35, n. 1-2, p. 35-47, 2005.

COHEN, Jeffrey Jerome. A cultura dos monstros: sete teses. SILVA, Tomaz Tadeu da (Org.). Pedagogia dos monstros: os prazeres e os perigos da confusão de fronteiras. Belo Horizonte: Autêntica, 2000, p. 23-60.

COUlAngES, Fustel de. A Cidade Antiga. Trad. Fernando de Aguiar. São Paulo: Martins Fontes, 2004.

KAEFFER, José Ademar. Aula proferida em 10 de maio de 2018. Disciplina Colóquio Linguagens da Religião, Programa de Pós-Graduação em Ciências da Religião da Umesp. Não publicado.

KILPP, Nelson. Jonas. Petrópolis; São Leopoldo: Vozes; Sinodal, 1994.

JARES, Xesús R. Educação para a paz: sua teoria e sua prática. Porto Alegre: Artmed, 2002. LOPES, Mercedes. O livro de Jonas: uma história de desencontro entre um profeta zangado e um Deus brincalhão. São Paulo: Paulus, 2010.

SANTOS, Altierez Sebastião. Jeová contra os Orixá”. Revista Contemplação, vol. 1, n. 15, p. 165-185, 2017.

SANTOS, Altierez Sebastião. A convergência dogmática dos fundamentalismos. Revista Contemplação, vol. 1, n. 10, p. 68-81, 2015.

SANTOS, Altierez Sebastião. A narrativa religiosa do Vale do Amanhecer e a vocalização dos excluídos. Convenit Internacional, São Paulo, vol. 26, p. 39-54, jan-abr, 2018. 
SCHWANTES, Milton. Convite à compaixão: Interpretação e meditação a partir de Jonas 4.1-11. Revista Caminhando, vol. 11, n. 18, p. 13-24, jul-dez, 2006.

SICRE DÍAZ, José Luis. Introdução ao profetismo bíblico. Tradução de Gentil Avelino Titon. Petrópolis: Vozes, 2016.

MARTINS, José de Souza. Linchamentos: a justiça popular no Brasil. São Paulo: Contexto, 2015.

MORA, Vincent. Jonas. Tradução das Monjas Dominicanas. São Paulo: Paulinas, 1983.

QUINTÃO, Glauber Pereira. O grande peixe: monstruosidade e punição no Livro de Jonas e em A estranha nação de Rafael Mendes. Arquivo Maaravi, Belo Horizonte, vol. 3, n. 5, p. 29-43, out. 2009.

Submetido em: 7-5-2019

Aceito em: 11-6-2019 